\title{
OBSERVATIONS ON THE PALATE AND CHOANAE STRUCTURES IN MESOEUCROCODYLIA (ARCHOSAURIA, CROCODYLOMORPHA): PHYLOGENETIC IMPLICATIONS
}

\author{
MARCO BRANDALISE DE ANDRADE, REINALDO J. BERTINI \& \\ ANDRÉ EDUARDO PIACENTINI PINHEIRO \\ Núcleo de Evolução e Paleobiologia de Vertebrados, Instituto de Geociências e Ciências Exatas, \\ UNESP, Cx.P. 178, Campus Rio Claro, 13506-900, Rio Claro, SP, Brazil. \\ marcobranda@yahoo.com.br,rbertini@rc.unesp.br,paleolones@yahoo.com.br
}

\begin{abstract}
The palate and choanae structures are important to the study of the evolution in Crocodylomorpha. Notosuchians, sebecosuchians and other Mesoeucrocodylia show a considerable diversity of patterns. Some notosuchians (Mariliasuchus, Notosuchus, Sphagesaurus) possess important similarities with at least one sebecosuchian (Stratiotosuchus), especially the triangular-subtriangular choanae, and the exclusion of the pterygoid from the posterior border of the suborbital fenestra. The use of these characteristics may represent useful information in phylogenetic analysis and should always be described in detail.
\end{abstract}

Key words: Evolution, Crocodylomorpha, Notosuchia, Cretaceous, choana, palate.

RESUMO - As estruturas de palato e coanas têm importância em estudos sobre evolução em Crocodylomorpha. Notossúquios, sebecossúquios e outros Mesoeucrocodylia apresentam uma diversidade de padrões bastante consideravel. Alguns notossúquios (Mariliasuchus, Notosuchus, Sphagesaurus) compartilham semelhanças importantes com ao menos um sebecossúquio (Stratiotosuchus), especialmente coanas de forma geral triangularsubtriangular, além da exclusão do pterigóide do bordo posterior da fenestra suborbital. O uso destas características pode representar importante fonte de informação em análises filogenéticas e deve sempre ser descrita em detalhe.

Palavras-chave: Evolução, Crocodylomorpha, Notosuchia, Cretáceo, coana, palato.

\section{INTRODUCTION}

Among Crocodylomorpha, the anatomy and morphology of the palate and internal naris (choanae) are important in evolutionary studies and character definition. The traditional classification of crocodylomorphs was based for decades mainly on such structures, using the degree of development of palate and choanae general features as distinctive characters (Romer, 1956, 1966; Colbert, 1969; Iordansky, 1973; Langston, 1973; Buffetaut 1979, 1982; Carroll, 1988; Pough et al., 1993). Mesoeucrocodylia is an important group within Crocodylomorpha and includes both Eusuchia and several other species, better defined as non-eusuchian Mesoeucrocodylia (Wheatstone \& Whybrown, 1983). They includes a wide range of extinct (e.g. Geosaurus, Notosuchus, Sebecus, Trematochampsa) and extant forms (e.g. Caiman, Gavialis, Crocodylus). All Mesoeucrocodylia have a welldeveloped secondary bony palate and a nasopharyngeal duct, with a somewhat posterior choanae (Wheatstone \& Whybrown, 1983; Benton \& Clark, 1988; Clark, 1994).

All extant Crocodylomorpha are classified within Eusuchia and, in all of these, the bony palate is completely developed and the choanae have a posteriormost position (under the braincase) (Benton \& Clark, 1988; Clark, 1994; Brochu 1997, 2003). The choanae are completely enclosed by the pterygoids, in all cases. Throughout the entire group, the choanal morphology seems to be very conservative and readily recognizable (Brochu 1997, 2003), which means that this may be a good character to recognize an eusuchian among Mesoeucrocodylia, but poor information regarding eusuchian evolution.

The non-eusuchian Mesoeucrocodylia are also known as basal Mesoeucrocodylia and were formerly referred as Mesosuchia (Romer, 1956, 1966; Price, 1959; Colbert, 1969; Buffetaut 1979, 1982; Carroll, 1988; Hecht, 1991; Pough et al., 1993). Classical descriptions always define basal Mesoeucrocodylia as showing an incomplete secondary palate, shorter than the bony palate found in Eusuchia, and having the choanae placed in a more anterior position, between the palatines (anterior border) and pterygoids (posterior border) (Romer, 1956, 1966; Price, 1959; Colbert, 1969; Buffetaut, 1982; Carroll, 1988; Pough et al., 1993). Such description is mostly non-informative as phylogenetic information, especially regarding the evolution of 
Mesoeucrocodylia, and only allows the recognition of a species as a non-eusuchian. The extreme variability found in this group shows a great diversity of patterns that should be defined outside from the eusuchian/non-eusuchian dichotomy. Although new morphological information regarding the choanae has been added in recent studies (Clark, 1994; Martinelli, 2003; Pol \& Norell 2004a,b; Pol \& Apesteguia, 2005; Zaher et al., 2006), choanal morphology remains open to further description of characters and recognition of patterns among major groups.

The aim of this article is to describe a morpho-anatomical pattern regarding the structure of the choanae, common to at least three (possibly more) species of South American Mesoeucrocodylia. This pattern is different from other Crocodylomorpha, can be especially useful to distinguish them from other groups within Mesoeucrocodylia and allows the characterization of some major lineages. Such information can also provide new clues to understand mesoeucrocodyle evolution, as it has been a valuable tool in preliminary studies on the phylogeny of notosuchians and sebecosuchians (Andrade, 2005; Andrade \& Bertini, 2005; Andrade et al., 2005).

\section{MATERIALS}

We studied five notosuchians, one sebecosuchian, one eusuchian and one thalattosuchian. Information regarding other Mesoeucrocodylia was obtained from the current literature (Rusconi, 1933; Price, 1945, 1950, 1959; Wu et al., 2001; Martinelli, 2003; Sereno et al., 2003; Pol, 2003; Pol \& Apesteguia, 2005; Turner, 2006; Zaher et al., 2006).

\begin{abstract}
Abbreviations
Institutional abbreviations. MACN, Museo Argentino de Ciencias Naturales, Buenos Aires, Argentina; MLP, Museo de La Plata, La Plata, Argentina; MOZ, Museo Profesor-Dr. Juan A. Olsacher, Zapala, Argentina; MPCA, Museo Carlos Ameghino Cipoletti, Argentina; MPMA, Museu de Paleontologia de Monte Alto, Monte Alto, Brazil; MUCPv, Museo de la Universidad del Comahue, Neuquén, Argentina; SMNH, Royal Saskatchewan Museum (formerly Saskatchewan Museum of Natural History), Regina, Canada; UFRJ, Universidade Federal do Rio de Janeiro, Rio de Janeiro, Brazil; URC, Museu de Paleontologia e Estratigrafia Prof. Dr. Paulo Milton Barbosa Landim, Universidade Estadual Paulista, Rio Claro, Brazil.
\end{abstract}

Anatomical abbreviations. Bo, basioccipital; Bs, basisphenoid; c, caniniform; Den, dentary; Ecpt, ectopterygoid; Esp, splenial; FMP, maxillo-palatine fenestrae; FPC, paracanine fossa; FSO, suborbital fenestra; Ju, jugal; Mx, maxilla; NI, internal naris (choana); Pal, palatine; Pt, pterygoid; PtD, pterygoid depression; Qj, quadratojugal; Qu, quadrate; SIC, interchoanal septum.

\section{Studied materials}

Among the Notosuchia (sensu Gasparini, 1971) we studied: (i) one specimen of Mariliasuchus amarali (URCR.67); (ii) one specimen of Sphagesaurus sp. (MPMA-15-
001/90); (iii) several specimens of Notosuchus terrestris (especially MACN-N-23, MACN-RN-1037, MACN-RN-1038, MACN-RN-1040, MACN-RN-1045 and MLP-64-IV-16-5); (iv) one specimen of Comahuesuchus brachybuccalis (MOZ-P6131); and (v) one specimen of Araripesuchus patagonicus (MUCPv-269). Besides those materials, one specimen of the sebecosuchian Stratiotosuchus maxhechti (URC-R.73), one extant eusuchian Caiman crocodilus (URC-R.76) and one thalattosuchian, Geosaurus araucanensis (MLP-72-IV-7-1), could also be studied for comparison. Information on Sphagesaurus huenei was obtained both from a RCL-100 cast and from Pol (2003).

It is important to state some problems regarding the study of the fossil materials, concerning the description of choanae and its characters. In Notosuchus terrestris it is especially difficult to study the palatal and perichoanal structures, due mostly to the preservation of the specimens. Although there are a very good number of Notosuchus materials, the interchoanal septum is mostly preserved and readily recognizable only in one of the specimens studied (MACNRN-1038). Among known specimens of Comahuesuchus brachybuccalis, only MOZ-P-6131 shows preservation of part of the choanae structure. Furthermore the description of species may also include material that needs further work, especially at the palate/choanae region, as preparation may damage the structure or the specimens.

\section{RESULTS}

Among the Mesoeucrocodylia, the pattern described here is very peculiar in its general shape and morphology, and was recognized at first within this study in the notosuchians Mariliasuchus, Notosuchus (Figure 1) and Sphagesaurus (Figure 2). Afterwards, the same pattern could be identified in the baurusuchid Stratiotosuchus (Figure 2), and the notosuchian Comahuesuchus may also shows it (Figure 1). All these genera have large choanae, with the general shape varying from triangular to subtriangular, and the vertex pointing forward (Figures 1 and 2). In fact, the shape of the internal naris (choanae) alone can be used to readily distinguish them from other Crocodylomorpha, either extant or fossil (e.g. Alligator, Crocodylus, Araripesuchus, Geosaurus), provided the material is not deformed or damaged.

Although the structures related to the choanae are not well preserved in the known specimens of Comahuesuchus, the condition observed in MOZ-P-6131 (Figure 1), as described by Martinelli (2003), is fairly similar to the pattern described here, and is mostly similar to what can be seen in Mariliasuchus and Sphagesaurus. In fact, the reconstruction of the choanal area by Martinelli (2003:fig. 2) resulted in a triangular overall shape (Figure 1).

\section{Morphology of the triangular type of choanae}

Besides the overall shape, the morphology is also easily recognizable and most features are generally common to Mariliasuchus, Notosuchus, Sphagesaurus and Stratiotosuchus, although a few important variations can be seen for 
Notosuchus and Stratiotosuchus (Figures 1 and 2). The anterior margin of the choanae is formed by the palatines, which separate the suborbital fenestrae, delimiting their internal borders. At the posterior end of the palatines (anterior margin of the internal naris), there is an extended pair of gracile and elongate postero-lateral processes that reach the ectopterygoids, also making contact with the pterygoid. The palatine postero-lateral process thus composes a bar that delimits the lateral borders of the choana and separates it from the suborbital fenestra, as seen in Mariliasuchus (URCR.67) and Sphagesaurus (MPMA-15-001/90). Regarding previously figured specimens, this last feature is not preserved in Sphagesaurus DGM 1411-R (Kellner \& Campos, 1999), RCL-100 (Pol, 2003) and Stratiotosuchus DGM-1477-R (Campos et al., 2001; Riff, 2003), but can be easily seen in Comahuesuchus MOZ-P-6131 (Martinelli, 2003), Mariliasuchus UFRJ DG 105-R, UFRJ DG 106-R (Vasconcellos \& Carvalho, 2005:58, fig. 5), MZSP-PV 50 (Zaher et al., 2006:8, fig. 4) and Notosuchus MACN-RN-1040 (Martinelli, 2003).

An exception to this pattern can be made for Notosuchus terrestris, as described previously by Martinelli (2003), and Stratiotosuchus maxhechti, as reported here. In Notosuchus MACN-RN-1038 the palatine process is somewhat flattened, shorter and stout (although in MACN-RN-1040 it is more gracile and with a roundish cross-section). The ectopterygoid process develops mesially, making contact with the palatines much closer to the choanae, which means that the palatine does not contact the pterygoid (Martinelli, 2003). This also means that the ectopterygoid must take part in the border of the choanae. The same situation can be seen in Stratiotosuchus maxhechti URC-R.73 (Pinheiro et al., 2005), although the general structure of the bony elements is far more robust. In this species the bar formed by the ectopterygoid mesial process, and the palatine postero-lateral process, is extremely wide and thick, when compared to any other notosuchians studied.

As a result of the contact between the ectopterygoid and the palatine, the pterygoid is always excluded from the suborbital fenestra. This is a situation common to Comahuesuchus, Mariliasuchus, Notosuchus, Sphagesaurus and Stratiotosuchus, despite the differences previously stated for Notosuchus and Stratiotosuchus. This is not exclusive to the species treated here, though some other Mesoeucrocodylia may also show this feature, possibly Candidodon and at least part of the Sebecosuchia.

Another feature that is commonly found in many Mesoeucrocodylia, as in most of these forms, is the presence of a thin interchoanal septum, except for Sphagesaurus and Stratiotosuchus (Figure 2). Furthermore, at least in Mariliasuchus and Notosuchus, there seems to be an enlarged portion of the septum as it reaches the choanal surface, which in cross section would give the septum a "T" shape (Figure 1).

The posteriormost margin of the choanae is entirely composed by the pterygoids, for studied specimen of Mariliasuchus, Notosuchus, Sphagesaurus and Stratiotosuchus, but still unknown for Comahuesuchus. The pterygoid bone forms a straight surface at the back of the internal naris and can be readily identified (Figures 1 and 2), so long as it is observed in strict palatal view. This gives the characteristic triangular shape of the structure. Nevertheless, this posterior border of the choanae is not in the same horizontal plane as the anterior border. Thus, the anterior border, composed by palatines, is not at the same level of the posterior border, composed by the pterygoids. Also the pterygoid surface is uneven in the horizontal plane, with a concave surface. This all means that
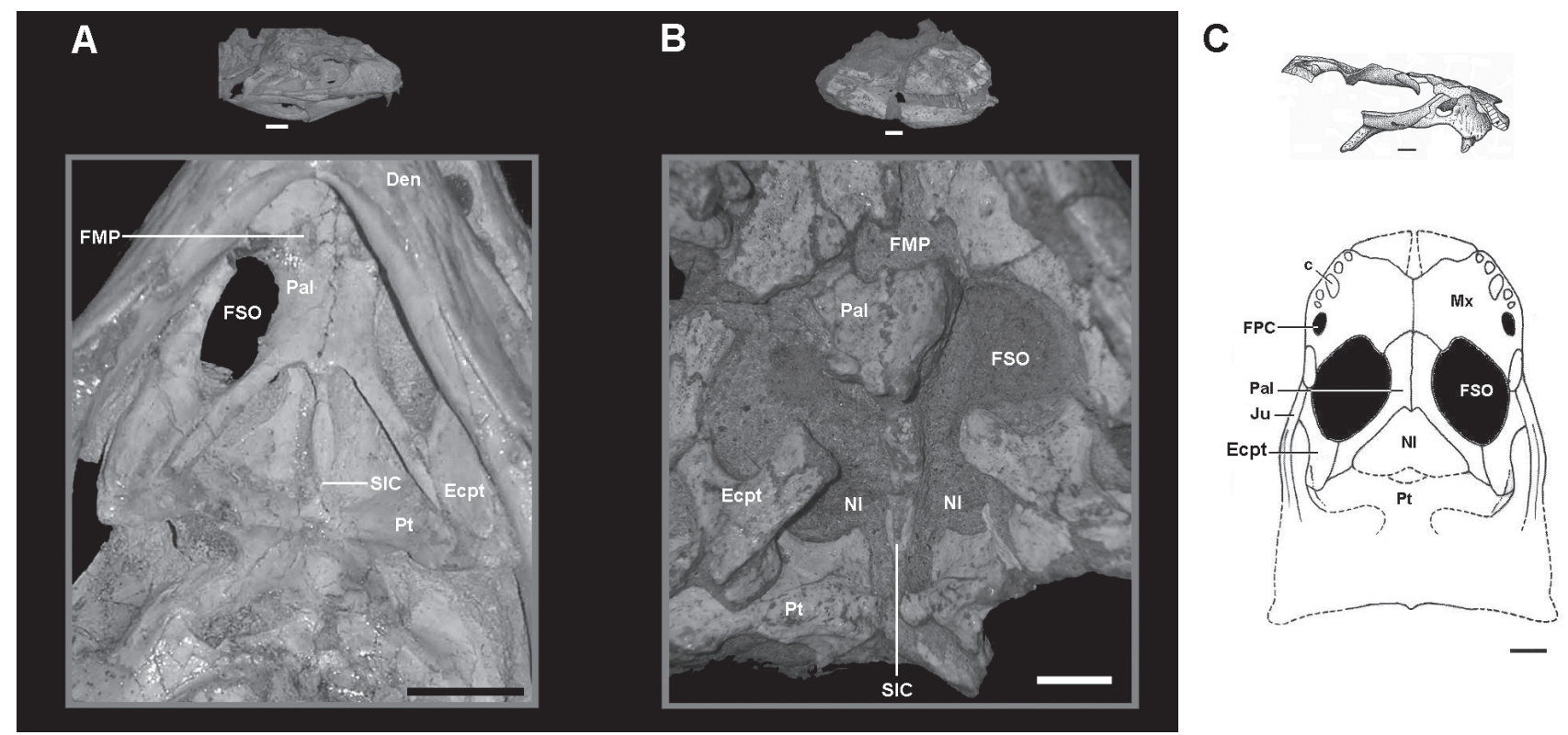

Figure 1. General aspect of the skull of notosuchians Mariliasuchus and Notosuchus, with detail from the triangular-subtriangular choanae, compared to Comahuesuchus. A, Mariliasuchus amarali URC-R.67; B, Notosuchus terrestris MACN-RN-1038; C, palatal view of Comahuesuchus brachybuccalis MOZ-P-6131, as reconstructed by Martinelli (2003). Scale bar = $10 \mathrm{~mm}$. 
an observer may see a subtriangular shape instead of a triangular one, depending on the position of the fossil as it is examined. Examples of the subtriangular shape can be seen in the current literature for Mariliasuchus amarali, both in Vasconcellos \& Carvalho (2005:58, fig. 5) and Zaher et al. (2006:8, fig. 4).
Further notes on Sphagesaurus and Stratiotosuchus choanal morphology

Apart from the characters previously described, some other aspects of the morphology of Sphagesaurus and Stratiotosuchus should also be noted, as previously described material (Sphagesaurus huenei in Pol, 2003;
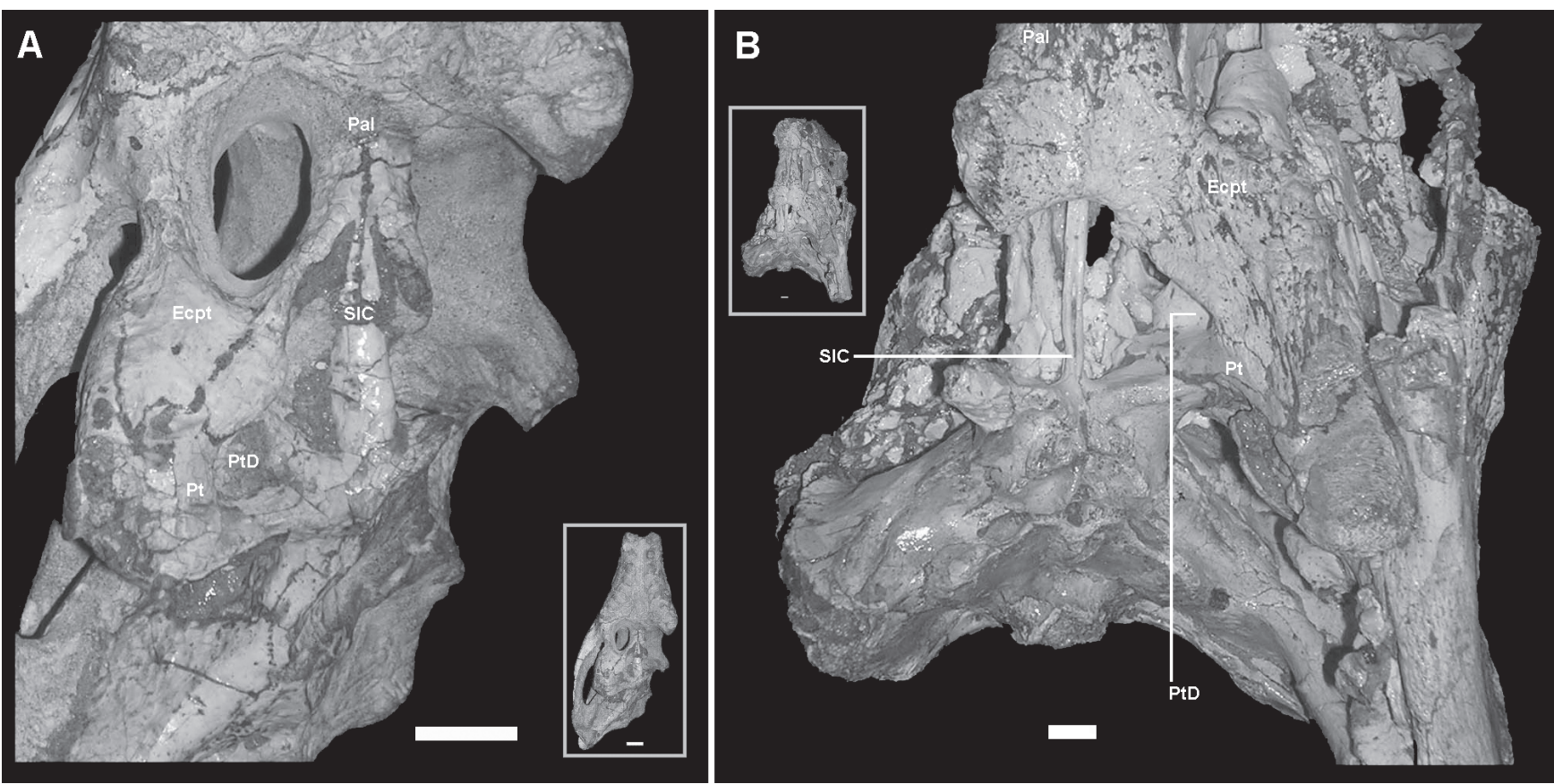

Figure 2. General aspect of the skull of the notosuchian Sphagesaurus and the baurusuchid Stratiotosuchus, with detail from the triangular-subtriangular choanae. A, Sphagesaurus sp. MPMA-15-1/90; B, Stratiotosuchus maxhechti URC-R.75. Note the position of the pterygoid depressions and their orientation. Scale bar $=10 \mathrm{~mm}$.
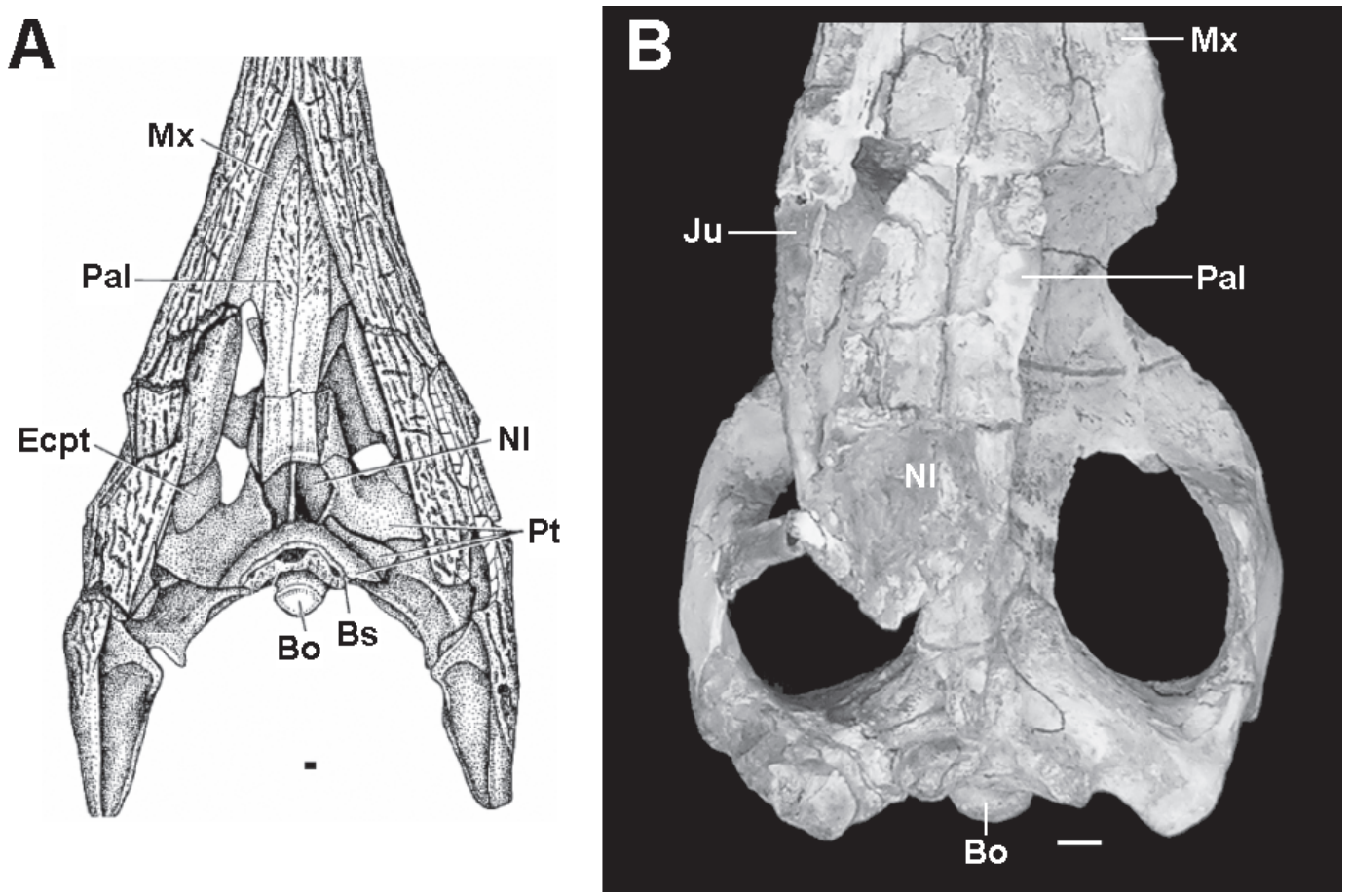

Figure 3. Palatal view from Mesoeucrocodylia with subcircular choanae. A, Terminonaris robusta SMNH-P-2411.1 (adapted from Wu et al., 2001); B, Geosaurus araucanensis MLP-72-IV-7-1, holotype. Scale bar $=10 \mathrm{~mm}$. 
Stratiotosuchus maxhechti in Campos et al., 2001; Riff, 2003) does not preserve significant choanal structures. Information described here was provided mostly by Sphagesaurus MPMA-15-001/90 and Stratiotosuchus URC-R.73. Some of the new features are unique to each of these species.

The interchoanal septum, for instance, seems to be developed in a most unusual manner in Stratiotosuchus. At least within the limits of the choanal opening, the septum itself is gracile and reduced, remaining developed only at the inferiormost section and thus not really keeping apart the two halves of the internal naris. The result is that the structure remains as a bar, at the surface of the choanal opening. This interchoanal bar has a triangular cross-section that does not resemble any other related species (Figure 2). The presence of an interchoanal septum could not be verified in Sphagesaurus MPMA-15-001/90 due to the occurrence of stone matrix. Still, the specimen retains the septum surface over the choanal opening, not preserved in RCL-100. This septum surface is extremely robust when compared to the septum of all other Mesoeucrocodylia, and is stronger in its posterior section than to the anterior one (Figure 1). In cross section this structure seems to be subcircular and probably supported a thin lamina dividing the internal naris, as seen in S. huenei RCL-100 (Pol, 2003).

On the ventral surface of the pterygoids, a pair of depressions can be easily identifiable, positioned laterally to the internal naris. These are found exclusively in
Sphagesaurus (MPMA-15-1/90) and Stratiotosuchus (URCR.73) (Figure 2). These structures are more probably fenestrae, although their exact nature is still not established, due to the difficulty to clean the associated sandstone matrix from the bony structures. They may be, or may be not, homologous to the pterygoid fossae identified in Sphagesaurus huenei by Pol (2001), but the incompleteness of the RCL-100 specimen does not allow a trustworthy comparison. These depressions may not even be homologous between Sphagesaurus and Stratiotosuchus, as they are not positioned in the exact same region and in preliminary analysis their presence appears as convergent character-states (Andrade, 2005; Andrade \& Bertini, 2005). In Sphagesaurus MPMA-15-001/90 these depressions are located laterally to the posteriormost border of the choanae, facing more ventraly than mesially. In Stratiotosuchus RCL-R.73 the depressions are at a more anterior position, lateral to the choanae, and face more medially than ventrally. The participation of other bony elements to the border of these depressions is also different, although in both cases these depressions are mostly housed within the pterygoid surface. In Sphagesaurus the palatine postero-lateral process extends far behind the border of the suborbital fenestra, and partially reaches the anterior-lateral border of the depression. In Stratiotosuchus, on the other hand, the extremely robust mesial process of the ectopterygoid reaches extensively the anterior and lateral borders of the depression, taking part of this structure.
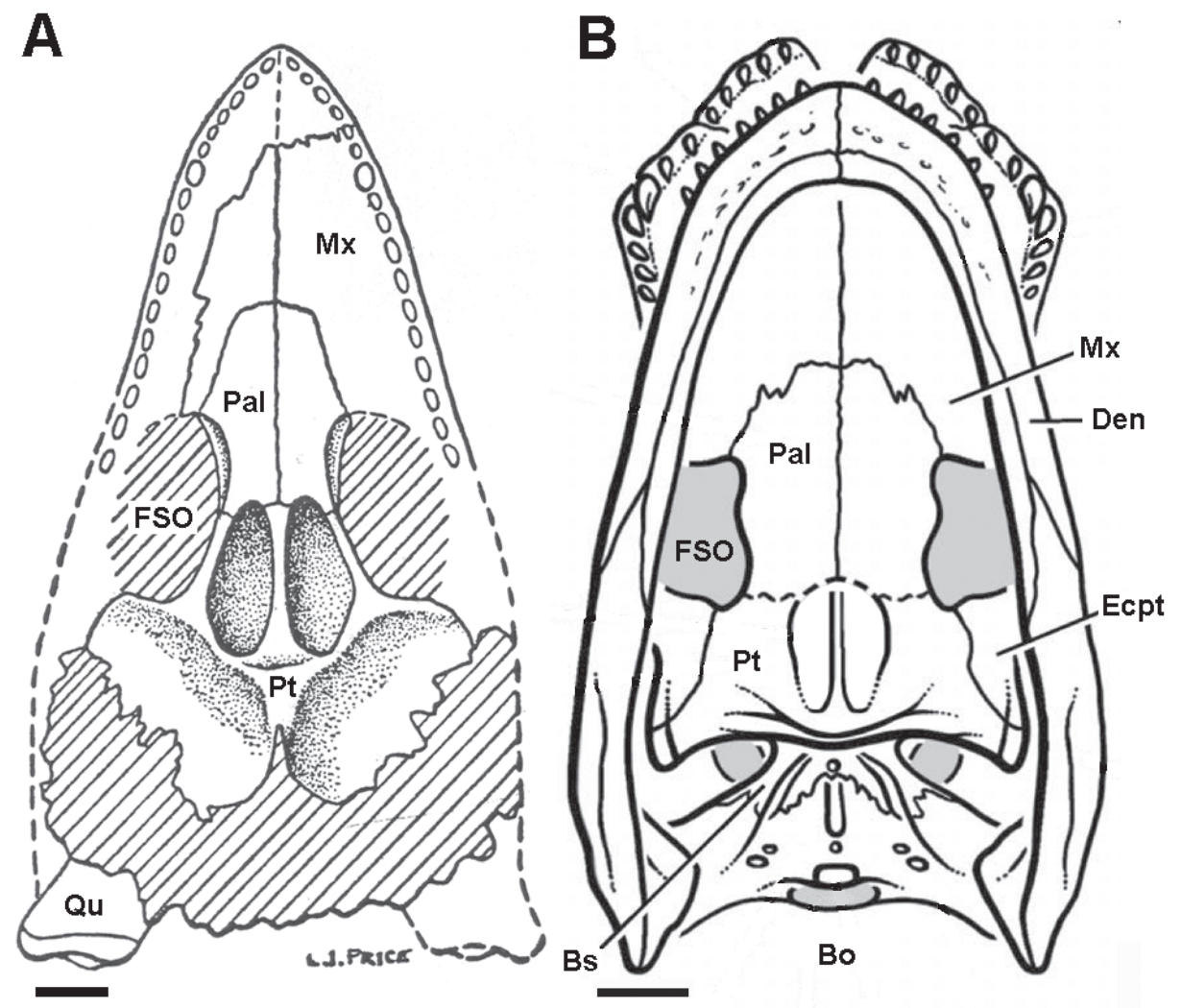

Figure 4. Palatal view from Mesoeucrocodylia with elliptical choanae. A, Uruguaysuchus (adapted from Price, 1959); B, Anatosuchus (adapted from Sereno et al., 2003). Note the differences between the development of the palatines, as they contact the pterygoid. Scale bar $=10 \mathrm{~mm}$. 


\section{DISCUSSION}

\section{Choanae morphological variation within major lineages of Mesoeucrocodylia}

The triangular choanae pattern is characteristic of Mariliasuchus, Notosuchus, Sphagesaurus and Stratiotosuchus (Figures 1 and 2). This pattern is also matches every other aspect preserved in Comahuesuchus, and any discrepancies are the result of the incompleteness of the material currently available, not from opposing morphologic features. Other Mesoeucrocodylia, on the other hand, show many differences either in their general shape or morphological patterns (Figures 3 to 6).

A subcircular internal naris (Figure 3) can be found in several species of aquatic/semi-aquatic non-eusuchian Mesoeucrocodylia, as in Geosaurus, Sarcosuchus and Terminonaris, with significant variation in size and composition. More readily recognizable types of choanae can also be found in basal terrestrial Mesoeucrocodylia. In Anatosuchus and Uruguaysuchus the internal naris is elliptical (Figure 4), slightly longer than wide (although this resemblance may be the result of general shape similarities, rather than composition). In most species of Araripesuchus (A. buitreraensis, A. gomesii and A. patagonicus), where the choanal structure is well preserved, the overall shape is subrectangular (Figure 5), anteroposteriorly elongated, with parallel straight lateral margins (Price, 1959; Ortega et al., 2000; Pol \& Apesteguia, 2005). In the other species of the genus (A. tsangatsangana and A. wegeneri), either the choanae shape or its structure is not preserved and comparisons cannot be made (Buffetaut, 1981; Turner, 2006). The morphological condition found in Simosuchus seems to be unique, due to the relationships of palatines and pterygoid (Buckley et al., 2000), giving the choanae a trapezoidal shape. In Candidodon (Figure 6) the choanae seem to be particularly narrow and elongated (Nobre \& Carvalho, 2002), but the lack of details on the description of sutures hinders further comparisons. In both Chimaerasuchus and Uberabasuchus the structure is not preserved (Wu \& Sues, 1996; Carvalho et al., 2004).

Differently from all other Mesoeucrocodylia, eusuchians show a particularly short type of internal naris, which is much wider than longer. This structure is proportionally very small when compared to most Mesoeucrocodylia. Furthermore, in Alligatoridae it shows an overall reversed triangular shape (Figure 6), with the vertex posteriorly oriented (instead of anteriorly oriented, as for Mariliasuchus and similar forms). It should also be noticed that none of the other previously referred Mesoeucrocodylia were reported as having the choanal posterior border as straight as it is found for Mariliasuchus, Notosuchus, Sphagesaurus and Stratiotosuchus.

The development of the pterygoid, ectopterygoid and palatines is also highly variable within Mesoeucrocodylia. Both Notosuchus and Stratiotosuchus share the extreme development of the ectopterygoid mesial process. The palatine-ectopterygoid contact may prevent the pterygoid from participation in the
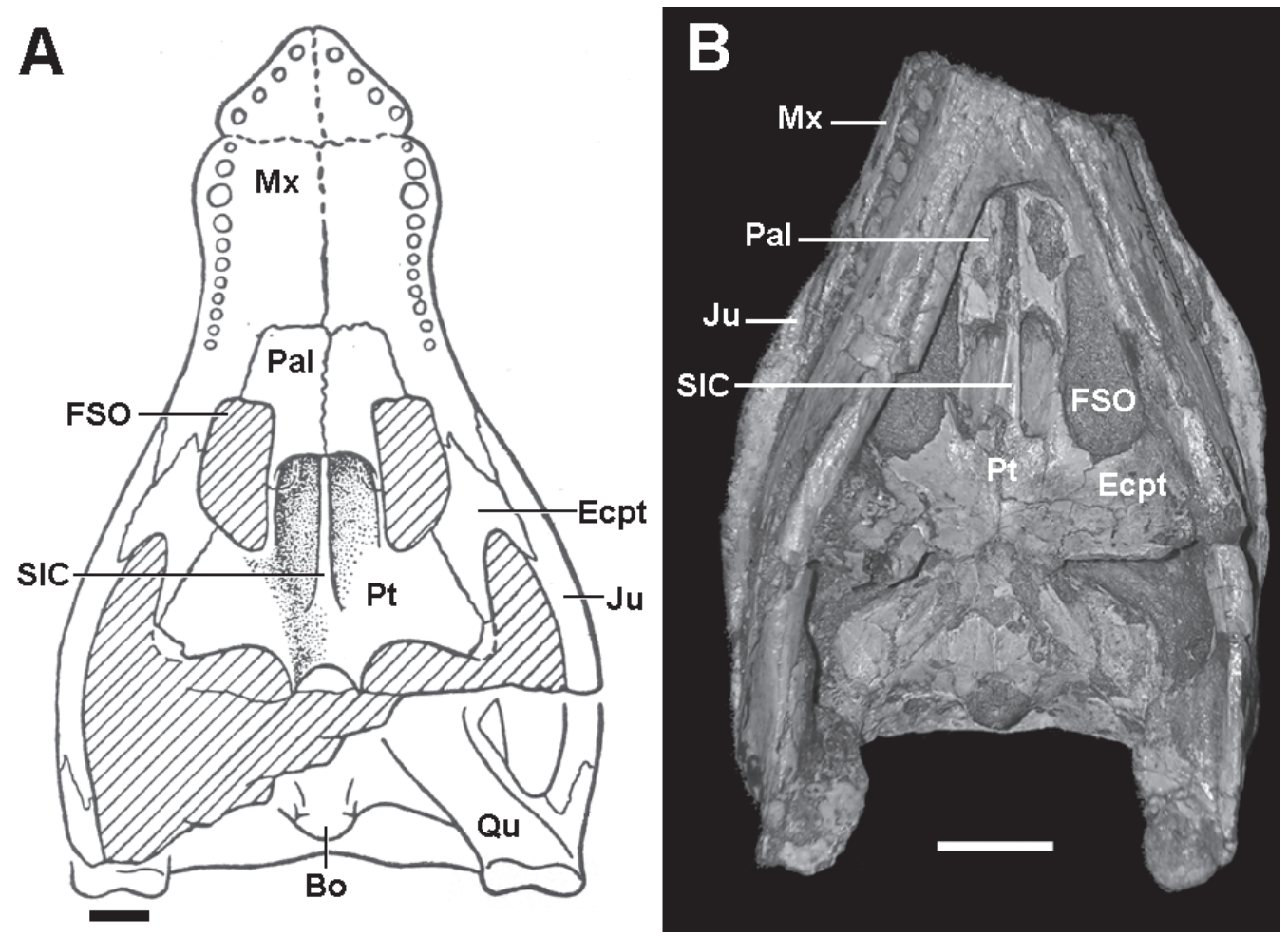

Figure 5. Palatal view of the skull from Araripesuchus, showing the subrectangular choanal pattern, with parallel sides. A, Araripesuchus gomesii (adapted from Price, 1959); B, Araripesuchus patagonicus MUCPv-269, holotype. Scale bar $=10 \mathrm{~mm}$. 

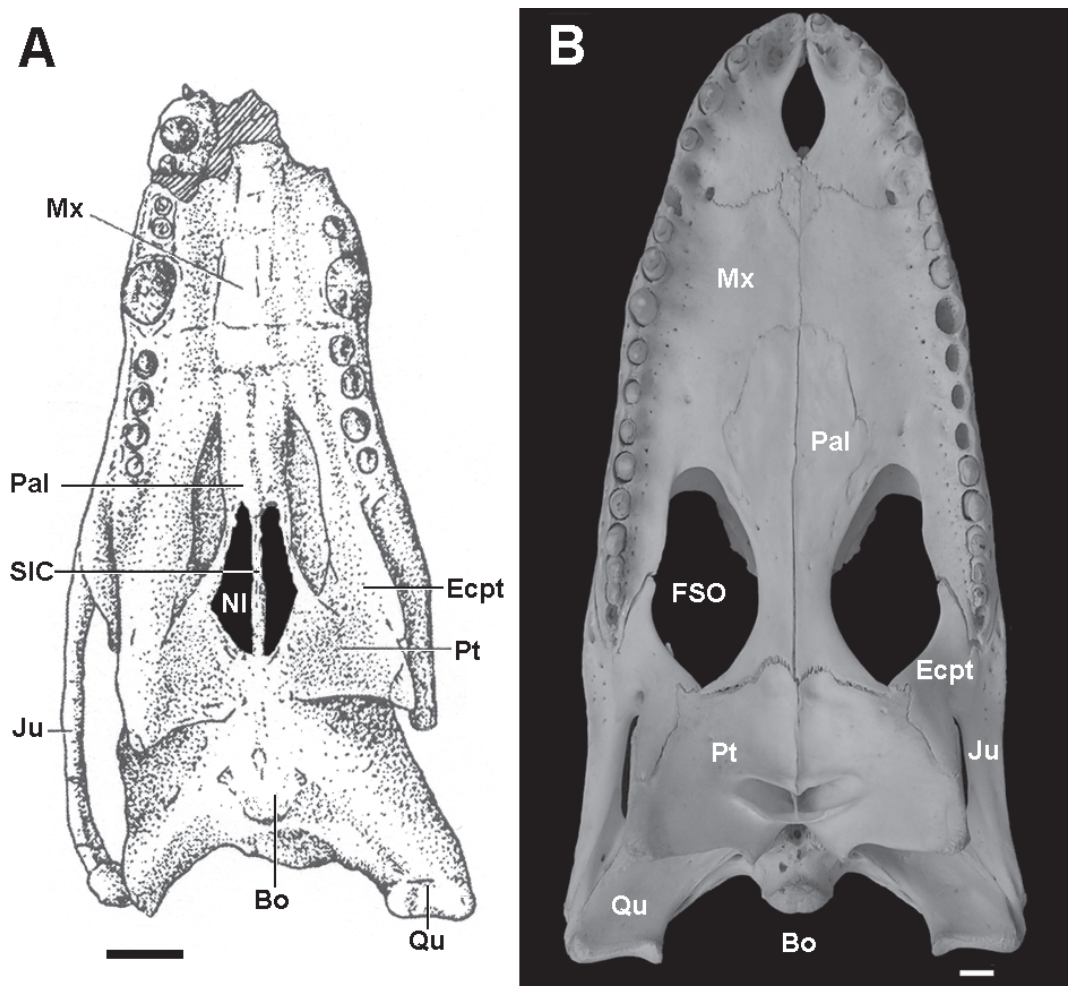

Figure 6. Characteristic types of choanae, as seen in different groups of Mesoeucrocodylia. A, palatal view of Candidodon itapecuruense UFRJ-DG-114-R, with extremely elongated choanae (adapted from Nobre \& Carvalho, 2002); B, palatal view of Caiman crocodilus URCR.76, with the reversed triangle type of choanae. Scale bar $=10 \mathrm{~mm}$.

border of the suborbital fenestra in Comahuesuchus, Mariliasuchus, Notosuchus, Sphagesaurus and Stratiotosuchus. In several other groups of Mesoeucrocodylia, the pterygoids make a significant contribution to the postero-medial border of the suborbital fenestra. This is true at least for Anatosuchus, Araripesuchus, Sarcosuchus, Simosuchus and Terminonaris (Price, 1959; Buckley et al., 2000; Ortega et al., 2000; Wu et al., 2001; Sereno et al. 2001, 2003). The situation remains unclear for certain other taxa where neither the material, nor its description, really presents the morphology. The pterygoid seems to participate in the suborbital fenestrae in Malawisuchus, as pointed out by Martinelli (2003, based in drawings from Gomani, 1997) and possibly in Sebecus, Uberabasuchus and Uruguaysuchus (Rusconi, 1933; Colbert, 1946; Price, 1959; Carvalho et al., 2004). In Candidodon there may be contact between ectopterygoid and palatine (Nobre \& Carvalho, 2002), but again the lack of information on the sutures prevents better comprehension of the material.

Eusuchians themselves also show a variable condition, as the pterygoids may or may not contact the border of the fenestra, and whenever this may happen in Eusuchia, this contribution seems to be very small and the morphology is usually very similar. Nevertheless this variable condition happens because this group has a very characteristic morphology, that is: (i) the development of the palatines over the pterygoid, while (ii) the ectopterygoid remains limited to the postero-lateral margin of the suborbital fenestra. That means that the palatine postero-lateral process is at least very close to the ectopterygoyd and the pterygoid can only barely reach the suborbital fenestra. Any minor morphological variation may then lead to a contact between the palatine and the ectopterygoid, isolating the pterygoid from the suborbital fenestra (Figure 6B). Another exclusive feature of the eusuchians is the presence of a bony ridge at the external margin of the internal naris, as observed in the Caiman URCR.76 (Figure 6B; Iordansky, 1973; Brochu, 1997) that cannot be found in basal Mesoeucrocodylia.

The occurrence of an interchoanal septum is not much variable within major Mesoeucrocodylia lineages, and is present in a great number of them. Within the range included in this study, only Geosaurus does not show an interchoanal septum. One problem is that in some species it is difficult to determine if the structure is really absent or is not preserved and its existence is ignored. Although described as present by Woodward (1896) for Notosuchus, the interchoanal septum remained mostly ignored afterwards. It is in fact present in Notosuchus, as it is in Mariliasuchus (Andrade, 2005; Andrade \& Bertini, 2005; Fiorelli, 2005; Fiorelli \& Calvo, 2005; Zaher et al., 2006) and in Stratiotosuchus (Campos et al., 2001; Riff, 2003). Many other basal Mesoeucrocodylia, such as Araripesuchus, Candidodon, Malawisuchus, Sarcosuchus, Sphagesaurus, Simosuchus, Terminonaris and Uruguaysuchus also show a well developed septum, that is generally thin, but solid (Rusconi, 1933; Price, 1959; Gomani, 1997; Buckley et al., 2000; Ortega et al., 2000; Wu et al., 2001; Sereno et al. 2001, 2003; Nobre \& Carvalho, 2002; Pol, 2003; Pol \& Apesteguia, 2005). Eusuchians always have the 
interchoanal septum (Brochu, 1997) but, in contrast to basal Mesoeucrocodylia, this septum is thinner and gracile.

It is worth noticing that many features discussed here remain in fact ignored within the current literature on Mesoeucrocodylia, even when material is available in quantity and specimens can be studied (e.g. Baurusuchus, Candidodon, Itasuchus, Libycosuchus, Malawisuchus and Sebecus). Further field work should also provide materials in which the known specimens do not preserve the choanal region (Araripesuchus tsangatsangana, Araripesuchus wegeneri, Chimaerasuchus and Uberabasuchus) or even are kept in private collections (Caririsuchus and Uruguaysuchus).

Some features are not commonly described and figured, although they are also important to the study of the Mesoeucrocodylia, providing sensitive information that can be brought into phylogenetic analysis. The occipital region was described by Price (1959), Gasparini (1971), Bonaparte (1991), Andrade (2005) and Fiorelli (2005). Bonaparte $(1991,1996)$ and Martinelli (2003) commented on basicranium characters and the possible relationships between Notosuchus and Protosuchia. The importance of the postcranium material was well established by Pol $(1997,2005)$ and consistently used afterwards for available material (Pol, 2003; Pol \& Norell 2004a, b; Andrade, 2005; Fiorelli, 2005; Pol \& Apesteguia, 2005; Zaher et al., 2006). Ortega et al. (2000) described important features from the mandible articulation, quadrate condyle and retroarticular process of Araripesuchus and Notosuchus, afterwards used and extended for other clades in the phylogenetic analysis, including Pol (2003), Pol \& Norell (2004a, b), Andrade (2005), Andrade \& Bertini (2005), Fiorelli (2005), Fiorelli \& Calvo (2005), Pol \& Apesteguia (2005) and Zaher et al. (2006). In addition to those features, the description of choanal morphology can also provide further phylogenetic information.

\section{Choanal morphology and its phylogenetic implications for Mesoeucrocodylia}

The choanal region is a great source of phylogenetic information because of its complex nature. Each morphological pattern is the result of a combination of several bony elements and thus, for most species, can be a useful tool to identify possible evolutionary relationships. Among Mesoeucrocodylia at least five main patterns can be distinguished and are compatible with most phylogenies currently published, although these may not always represent apomorphic states. Elongated subrectangular choanae with parallel sides (Figure 5) are typical of all Araripesuchus with the structure preserved, corroborated by Ortega et al. (2000) and Turner (2006). The small reversed triangular choanae of alligatorids (Figure 6C) is also characteristic, allowing no mistakes on the identification of materials. Big elliptical choanae occur in Anatosuchus and Uruguaysuchus (Figure 4), and circular choanae can easily be found in Geosaurus, Sarcosuchus and Terminonaris (Figure 3).

The triangular pattern (Figures 1 and 2) can be identified in at least four genera (Mariliasuchus, Notosuchus, Sphagesaurus and Stratiotosuchus), all presenting: (i) ectopterygoid-palatine contact; (ii) elongated posterolateral palatine process that, at least, delimits both the posteromesial border of the suborbital fenestrae and the anterolateral border of the internal naris; (iii) pterygoid isolated from the border of the suborbital fenestra; (iv) at least an almost straight posterior border of the choanae. This choanal morphology supports a close relationship with Notosuchus and Baurusuchidae (Ortega et al., 2000; Sereno et al., 2003; Pol, 2003; Pol \& Norell 2004a, b; Andrade, 2005; Andrade \& Bertini; 2005; Andrade et al., 2005; Fiorelli, 2005, Fiorelli \& Calvo, 2005; Pol \& Apesteguia, 2005; Zaher et al., 2006). The triangular choanae are strong evidence against a close relationship between Mariliasuchus and Candidodon, proposed by Carvalho et al. (2004). Nonetheless they support either a Mariliasuchus-Comahuesuchus (Zaher et al., 2006) or a Mariliasuchus-Notosuchus relationship (Andrade, 2005; Andrade \& Bertini, 2005; Andrade et al., 2005; Fiorelli, 2005; Fiorelli \& Calvo, 2005).

Also for Stratiotosuchus, the choanal morphology is useful information to be compared with other Mesoeucrocodylia. The pattern itself is very similar to what is found in Notosuchus, mostly due to the way the ectopterygoid contacts the postero-lateral palatine process, excluding the pterygoid. It is also very similar to Mariliasuchus and Sphagesaurus and a brief revision of phylogenetic hypothesis published throughout shows that all those species are generally clustered with Baurusuchidae and Bretesuchidae (Ortega et al., 2000; Pol, 2003; Pol \& Norell, 2004b; Pol \& Apesteguia, 2005; Zaher et al., 2006). The only exception is for Stratiotosuchus itself, which was most recently included in a previous analysis (Fiorelli, 2005; Fiorelli $\&$ Calvo, 2005), appearing as the sister-group of Baurusuchus. Furthermore, the resemblance between Stratiotosuchus and Baurusuchus seems to be astonishing, considering the entire skull (Campos et al., 2001; Riff, 2003).

The morphology of Comahuesuchus is concordant with the triangular pattern whenever the choanal structures are preserved. It is yet more similar when compared to Mariliasuchus and Sphagesaurus, as in those genera the palatine postero-lateral process extends further, contacts the pterygoid at the posterior border of the suborbital fenestra, and at least slightly spreads over the pterygoid surface. This observation supports Martinelli (2003) in refuting the Anatosuchus-Comahuesuchus relationship, proposed by Sereno et al. (2003). Apart from other characters, a comparison between Anatosuchus and MOZ-P-6131 shows enormous discrepancies that do not support the inclusion of Anatosuchus in the Family Comahuesuchidae, as proposed by Martinelli (2003) (contra Sereno et al., 2003; Turner, 2006). This choanal pattern is also coincident with what is found in several published papers (Pol, 2003; Pol \& Norell, 2004b; Pol \& Apesteguia, 2005; Zaher et al., 2006).

In a more broad view, the information provided by the analysis widely supports cladistic papers already published on the issue, such as Martinelli (2003), Pol (2003), Pol \& Apesteguia (2005) and Zaher et al. (2006). This is also true for preliminary studies on the phylogenetic relationships of notosuchians (Andrade, 2005; Andrade \& Bertini, 2005; 
Andrade et al., 2005). In the case of the Notosuchia, the occurrence of several different patterns (e.g. subrectangular, elliptical, long and narrow choanae; differential pterygoid contribution to the suborbital fenestra) is here considered as strong evidence of a non-monophyletic condition. The relationship between at least a part of the sebecosuchians (excluding Sebecus ?) and a part of the notosuchians (excluding Araripesuchus, Candidodon, Malawisuchus, Simosuchus and Uruguaysuchus) is supported by the occurrence of this choanal triangular pattern, and also by the similarities of the ectopterygoid of the notosuchian Notosuchus and the sebecosuchian Stratiotosuchus.

It is also interesting to notice that despite some differences in stratigraphic distribution, Mariliasuchus, Sphagesaurus, Stratiotosuchus (Bauru Group, Brazil), Comahuesuchus and Notosuchus (Bajo de La Carpa Formation, Argentina), are all from the Upper Cretaceous of South America.

As for the known species, a great number do not have detailed and accurate information on the internal naris and perichoanal structures, for a variety of reasons. Many species need redescription and this should contribute extensively to knowledge regarding the evolution of the main lineages in Crocodylomorpha. Notosuchians such as Candidodon, Malawisuchus and Simosuchus surely deserve close attention to the material already known, as the sebecosuchians Baurusuchus pachecoi and Libycosuchus brevirostris. Further efforts to discover new specimens of Chimaerasuchus, Itasuchus, Uberabasuchus, Uruguaysuchus are surely important.

\section{ACKNOWLEDGMENTS}

The authors are grateful to A. C. Arruda-Campos (MPMA), M. S. Bargo (MLP), J. F. Bonaparte (MACN), J. O. Calvo (UNC; "Proyecto Dino"), Z. B. Gasparini (MLP), A. Kramarz (MACN), A. Martinelli (MACN), C. Muñoz (MPCA), F. Novas (MACN) and M. A. Reguero (MLP), for access to specimens under their care. We are truly grateful to A. Martinelli and D. Pol for the dedicated revision and the constructive criticism of the manuscript. We would also like to acknowledge M. J. Benton (DES-University of Bristol), for reading the manuscript and giving keen advice. and giving keen advice. The authors are also gratefull to R. G. Netto (Universidade do Vale do Rio dos Sinos; RBP) for her constant help and support during the editorial process. A. S. Abe and M. A. Micheli (IB-UNESP/Rio Claro) donated a deceased Caiman crocodilus to the URC collection, and S. P. Pinheiro (IB-UNESP/R.Claro) provided a place for preparation of the specimen, included in this study. Simon Powell (DES-University of Bristol) gave valuable directions on image treatment. Financial support during the study was provided by CAPES. MBA is currently supported by CNPq (proc. $\mathrm{n}^{\circ}$ 200381), as $\mathrm{PhD}$ student at the Department of Earth Sciences, Faculty of Science, University of Bristol, BS8 1 RJ, Queens Road, Clifton, Bristol, United Kingdom. This paper was a contribution to the XIX Congresso Brasileiro de Paleontologia/ VI Congresso Latino-americano de Paleontologia, held in August, 2005, in Aracaju (SE, Brazil).

\section{REFERENCES}

Andrade, M.B. 2005. Revisão sistemática e taxonômica dos Notosuchia (Metasuchia, Crocodylomorpha). Programa de PósGraduação em Geologia Regional, Universidade Estadual Paulista, Dissertação de Mestrado, 239 p.

Andrade, M.B. \& Bertini, R.J. 2005. Morphological and anatomical observations about Mariliasuchus amarali and Notosuchus terrestris (Mesoeucrocodylia), and their phylogenetical relationships with other "notosuchians" from South America. In: CONGRESSO LATINO-AMERICANO DE PALEONTOLOGIA DE VERTEBRADOS, 2, 2005. Boletim, Rio de Janeiro, Museu Nacional/UFRJ, p. 23-24.

Andrade, M.B.; Bertini, R.J. \& Pinheiro, A.E.P. 2005. Phylogenetical relationships of cf. Araripesuchus wegeneri (Archosauria: Crocodylomorpha). In: GEOLOGICAL AND BIOLOGICAL HERITAGE OF GONDWANA, 12, 2005. Abstracts, Academia Nacional de Ciencias, Mendoza, p. 44.

Benton, M.J. \& Clark, J.M. 1988. Archosaur phylogeny and the relationships of Crocodylia. In: M.J. Benton (ed.) The phylogeny and classification of the tetrapods. Clarendon Press, p. 295-338.

Bonaparte, J.F. 1991. Los vertebrados fósiles de la Formación Río Colorado, de la Ciudad de Neuquén y cercanías, Cretácico Superior, Argentina. Revista del Museo Argentino de Ciencias Naturales, 4(3):31-63.

Bonaparte, J.F. 1996. Cretaceous tetrapods of Argentina. Münchner Geowiss, 30:73-130.

Brochu, C.A. 1997. Phylogenetic systematics and taxonomy of Crocodylia. Geology Post-Graduate Program, University of Texas at Austin, PhD Dissertation, 495 p.

Brochu, C.A. 2003. Phylogenetical approaches toward crocodylian history. Annual Review of Earth Plannet Science, 31:357-97.

Buckley, G.A.; Brochu, C.A.; Krause, D. \& Pol, D. 2000. A pugnosed crocodyliform from the Late Cretaceous of Madagascar. Nature, 405:91-94.

Buffetaut, E. 1979. The evolution of the crocodilians. Scientific American, 241:130-144.

Buffetaut, E. 1981. Die Biogeographische Geschichte der Krokodilier, mit Beschreibung einer neuen Art, Araripesuchus wegeneri. Sonderdruck aus der Geologischen Rundschau, 70:611-624.

Buffetaut, E. 1982. Radiation evolutive, paléoécologie et biogéographie des crocodiliens mésosuchiens. Memoires de la Societé Géologique de France, 142:1-88.

Campos, D.A; Suarez, J.M.; Riff, D. \& Kellner, A.W.A., 2001. Short note on a new Baurusuchidae from the Cretaceous of Brazil. Boletim do Museu Nacional - Nova Série - Geologia, 57:1-7.

Carroll, R.L. 1988. Vertebrate paleontology and evolution. New York, Freeman, 698 p.

Carvalho, I.S.; Ribeiro, L.C.B. \& Avilla, L.S. 2004. Uberabasuchus terrificus sp. nov., a new Crocodylomorpha from the Bauru Basin (Upper Cretaceous), Brazil. Gondwana Research, 7:975-1002.

Clark, J.M. 1994. Patterns of evolution in Mesozoic Crocodyliformes. In: N.C. Fraser \& H-D. Sues (eds.) In the shadows of dinosaurs: early Mesozoic tetrapods. Cambridge University Press, p. 84-97.

Colbert, E.H. 1946. Sebecus, representative of a peculiar suborder of fossil Crocodylia from Patagonia. Bulletin of the American Museum of Natural History, 87:219-271.

Colbert, E.H. 1969. Evolution of the vertebrates. New York, John Wiley \& Sons, $535 \mathrm{p}$.

Fiorelli, L.E. 2005. Nuevos restos de Notosuchus terrestris 
Woodward, 1896 (Crocodyliformes: Mesoeucrocodylia) del Cretácico Superior (Santoniano) de la Provincia de Neuquén, Patagonia, Argentina. Carrera de Grado en Ciencias Biológicas, Universidad Nacional de Córdoba, Tesis de Licenciatura, 79 p.

Fiorelli, L.E. \& Calvo, J.O. 2005. Nuevos restos de Notosuchus terrestris Woodward, 1896 (Crocodyliformes: Mesoeucrocodylia) del Cretácico Superior (Santoniano) de la Provincia de Neuquén, Patagonia, Argentina. In: CONGRESSO LATINO-AMERICANO DE PALEONTOLOGIA DE VERTEBRADOS, 2, 2005. Boletim, Rio de Janeiro, Museu Nacional/UFRJ, p. 110-111.

Gasparini, Z.B. 1971. Los Notosuchia del Cretácico de América del Sur como un nuevo infraorden de los Mesosuchia (Crocodilia). Ameghiniana, 8:83-103.

Gomani, E.M. 1997. A crocodiliform from the Early Cretaceous Dinosaur Beds, Northern Malawi. Journal of Vertebrate Paleontology, 17(2):280-294.

Hecht, M.K. 1991. Araripesuchus Price, 1959. In: J.G. Maisey (ed.) 1991. Santana fossils: an illustrated Atlas. T.F.H. Publishers, p. 340-347.

Iordansky, N.N. 1973. The skull of Crocodilia. In: C. Gans \& T.S. Parsons (eds.), Biology of Reptilia: morphology D. London Academic Press, p. 201-262.

Kellner, A.W.A. \& Campos, D.A. 1999. Vertebrate paleontology in Brazil - a review. Episodes, 22:238-251.

Langston, W. 1973. The crocodilian skull in historical perspective. In: C. Gans \& T.S. Parsons (eds.), Biology of Reptilia: Morphology D. London Academic Press, p. 263-284.

Martinelli, A. 2003. New cranial remains of the bizarre notosuchid Comahuesuchus brachybuccalis (Archosauria, Crocodyliformes) from the Late Cretaceous of Río Negro Province (Argentina). Ameghiniana, 40:559-572.

Nobre, P.H. \& Carvalho, I.S. 2002. Osteologia do crânio de Candidodon itapecuruense (Crocodylomorpha, Mesoeucrocodylia) do Cretáceo do Brasil: In: SIMPÓSIO SOBRE O CRETÁCEO NO BRASIL, 6 / SIMPÓSIO SOBRE EL CRETÁCICO DE AMÉRICA DEL SUR, 2, 2002. Boletim, Rio Claro, UNESP, p. 77-82.

Ortega, F.; Gasparini, Z.; Buscalioni, A.D. \& Calvo, J.O. 2000. A new species of Araripesuchus (Crocodylomorpha, Mesoeucrocodylia) from the Lower Cretaceous of Patagonia (Argentina). Journal of Vertebrate Paleontology, 20:57-76.

Pinheiro, A.E.P.; Bertini, R.J.; Andrade, M.B. 2005. A new specimen of Stratiotosuchus sp (Baurusuchidae, Mesoeucrodylia) from the Adamantina Formation (Bauru Basin), Upper Cretaceous, Central São Paulo State (Southeastern Brazil). In: CONGRESSO LATINO-AMERICANO DE PALEONTOLOGIA DE VERTEBRADOS, 2, 2005. Boletim, Rio de Janeiro, Museu Nacional/UFRJ, p. 202-203.

Pol, D. 1999. El esqueleto postcraneano de Notosuchus terrestris (Archosauria : Crocodyliformes) del Cretácico Superior de la Cuenca Neuquina y su información filogenética. Programa de Grado en Biología, Universidad de Buenos Aires, Tesis de Licenciatura, $158 \mathrm{p}$.

Pol, D. 2003. New remains of Sphagesaurus (Crocodylomorpha: Mesoeucrocodylia) from the Upper Cretaceous of Brazil. Journal of Vertebrate Paleontology, 23:817-831.

Pol, D. \& Apesteguia, S. 2005. New Araripesuchus remains from the early Late Cretaceous (Cenomanian-Turonian) of Patagonia. American Museum Novitates, 3490:2-38.

Pol, D. \& Norell, M.A. 2004a. A new crocodyliform from Zos Canyon, Mongolia. American Museum Novitates, 3445:1-36.

Pol, D. \& Norell, M.A. 2004b. A new gobiosuchid crocodyliform taxon from the Cretaceous of Mongolia. American Museum Novitates, 3458:1-31.
Pough, F.H.; Heiser, J.B. \& McFarland, W.N. 1993. A vida dos vertebrados. São Paulo, Atheneu, 839 p.

Price, L.I. 1945. A new reptile from the Cretaceous of Brazil. Notas Preliminares e Estudos - DGM, 25:1-8.

Price, L.I. 1950. On a new crocodilian, Sphagesaurus, from the Cretaceous of the State of São Paulo, Brazil. Anais da Academia Brasileira de Ciências, 22(1):77-85.

Price, L.I. 1959. Sobre um crocodilídeo notossúquio do Cretáceo brasileiro. Boletim do Departamento Nacional de Produção Mineral, 188:1-55.

Riff, D. 2003. Descrição morfológica do crânio e mandíbula de Stratiotosuchus maxhechti (Crocodylomorpha, Cretáceo Superior do Brasil) e seu posicionamento filogenético. Programa de Pós-Graduação em Ciências Biológicas (Zoologia), Universidade Federal do Rio de Janeiro, Dissertação de Mestrado, 175 p.

Romer, A.S. 1956. Osteology of the Reptiles. Chicago, Chicago University Press, $772 \mathrm{p}$.

Romer, A.S. 1966. Vertebrate paleontology. $3^{\text {th }}$ ed., Chicago, Chicago University Press, 468 p.

Rusconi, C. 1933. Sobre reptiles cretáceos del Uruguay (Uruguaysuchus aznarezi, n.g. n. sp.) y sus relaciones con los notosúchidos de Patagonia. Boletin del Instituto de Geología y Perforaciones, 19(8):1-64.

Sereno, P.C.; Larsson, H.C.E.; Sidor, C.A. \& Gado, B. 2001. The giant crocodyliform Sarcosuchus from the Cretaceous of Africa. Science, 294:1516-1519.

Sereno, P.C. ; Sidor, C.A.; Larsson, H.C.E. \& Gado, B. 2003. A new notosuchian from the Early Cretaceous of Niger. Journal of Vertebrate Paleontology, 23:477-482.

Turner, A.H. 2006. Osteology and phylogeny of a new species of Araripesuchus (Crocodyliformes: Mesoeucrocodylia) from the Late Cretaceous of Madagascar. Historical Biology, 18:255-369.

Vasconcellos, F.M. \& Carvalho, I.S. 2005. Estágios do desenvolvimento de Mariliasuchus amarali, Crocodyliformes Mesoeucrocodylia da Formacao Adamantina, Cretáceo Superior da Bacia Bauru, Brasil. Anuário do Instituto de Geociencias, 28:49-69.

Whetstone, K.N. \& Whybrow, P.J. 1983. A “cursorial” crocodilian from the Triassic of Lesotho (Basutoland), Southern Africa. Occasional Papers of the Museum of Natural History of the University of Kansas, 106:1-37.

Woodward, A.S. 1896. On two Mesozoic crocodilians, Notosuchus (genus novum) and Cynodontosuchus (genum novum) from the red sandstones of the Territory of Neuquén (Argentine Republic). Anales del Museo de La Plata - Série Paleontologia Argentina, 4(1-2):1-20.

Wu, X-C; Russell, A.P. \& Cumbaa, S.L. 2001. Terminonaris (Archosauria: Crocodyliformes): new material from Saskatchewan, Canada, and comments on its phylogenetic relationships. Journal of Vertebrate Paleontology, 21:492-514.

Wu, X-C. \& Sues, H-D. 1996. Anatomy and phylogenetic relationships of Chimaerasuchus paradoxus, an unusual crocodyliform reptile from the Lower Cretaceous of Hubei, China. Journal of Vertebrate Paleontology, 16(4):688-702.

Zaher, H.; Pol, D; Carvalho, A.B.; Ricomini, C.; Campos, D. \& Nava, W. 2006. Redescription of the cranial morphology of Mariliasuchus amarali, and its phylogenetic affinities (Crocodyliformes, Notosuchia). American Museum Novitates, 3512:1-40.

Received in October, 2005; accepted in October, 2006 